\title{
Literature Society and Culture in Education Childhood Literature History
}

\author{
Emilia Conforti \\ LISE Department, University of Calabria, Cosenza, Italy \\ E-mail: emilia.conforti@unical.it
}

Doi:10.7575/aiac.alls.v.6n.5p.73

Received: $15 / 05 / 2015$

URL: http://dx.doi.org/10.7575/aiac.alls.v.6n.5p.73

Accepted: 20/07/2015

\begin{abstract}
This essay takes issue with earlier critical work arguing early British children's literature functions to construct middle class subjectivites. Using the John Newbery Medal as a case study, this essay examines the prizing of children's literature and its cultural discontents. The author uses a third-person limited omniscient point of view to demonstrate the necessity of perspective and sympathy for moral growth. Children's rights have become a significant field of study during the past decades.
\end{abstract}

Keywords: literary concepts, understanding childhood, childhood endorsement, according literature, childhood contribution

\section{Introduction}

\subsection{The early intervention of the concept of children}

Children's literature is very important for the child's training.

The world around him often appears as difficult to understand and upsetting. He needs help to understand what happens in his mind and outside. The parents represent, of course, the most element in this context. In the second place there is our cultural heritage, that has to be transmitted to the child in the right way.

When the child is little, the fairy tale is the literary form with he comes in contact. Fairy tale is a literary form known all over the world, in every society and country. Therefore the fairy tale is universal, but not only because it is universally present, but also because it enters in contact with whoever.

Fairy tale express natural situations, that are lived by everybody in different moments and different countries.

Bruno Bettleheim wrote in "The uses of Enchantment: The meaning and Importance of fairy Tales" (1976) what means about the fairy tale, he thinks it forms children personality.

\section{2 childhood image in English literature}

In western culture the emphasis on the child is a relatively recent invention, and literature for children, therefore, even more recent.

Moral instruction is the principal characteristic of children' literature before and after the Act of Uniformity of 1662. Puritans do not hide the virtuous aims of children' literature: spiritual salvation and the conversion of the young sinner, because as Helvetius argues "Man is, nothing more than the product of his education".

For entertainment children have romances, travel book and any "adult" reading they could read, for example Defoe's Robinson Crusoe (1719) or Swift's Gulliver Travel. By the late eighteen century, before their decline, these stories had, in their chap-book form, reached their bare bones: they had been pared down to their essential, irreducible, active elements, their frequently exotic heroes and mostly been shaken down into a state of homely naturalization; reduced to a sheer primal kind of narrative, the narrations pass at once in actions, and allow their events to speak wondrously for themselves ${ }^{1}$. These narrative conventions are, of course, ideally situated to unsophisticated listener and readers, young and old alike; and their reaction, must have played some part in the evolution of the narrative manner. But there were deeper reason for their popularity, especially among powerless, subordinate audience, for many of the tales express fantasies of power and wealth, achieved either through the operation of fortune, through magic, or through feats of courage, cunning, strength or endurance. The small hero, usually of modest birth, defeats the larger, richer, more politically and socially powerful foe; the odds are all stacked against the puny, insignificant hero, but he not only endures, he prevails ${ }^{2}$.

\section{Step by step towards a real children' literature}

In England one of the first author interested in children's book is John Newbery and his two best known publications are "A little pretty pocket book" (1744) and "The history of a little goody two-shoes". The preface of these stories addressed to parents, offered a series of moral and educational commonplaces, and when Newbery addresses his young

\footnotetext{
${ }^{1}$ Summerfield Feoffrey, Fantasy and Reason, Methuen \& Co. Ltd. London, 1984, p. 30

${ }^{2}$ Summerfield Geoffrey, op. cit., p. 30
} 
readers directly he praises them for their obedience, kindness and complaisance, for their refusal to swear, lie and use obscenities and for their pious acceptance of adult advice. The centre of the Pocket-Book is a series of wood cuts get various games, almost exclusively boys; underneath each picture is a feeble quatrain, describing the game, and then another quatrain, or a couple, offering a gloss, a moral or a "Rule of Life"3

Then there is an increasing number of publication for children in Europe and in America. Outstanding works are: Grimm's "Fairy Tales"4 (1839), Thackerey's "The Rose and the Ring" (1855) and the famous Carrol's "Alice's adventures in wonderland" (1865). And it is just with this tale, Encyclopaedia Britannica (ed. 1966, vol. 5, p. 520) fixes the beginning of the "Golden Age" about literature for children. The tale is a mix of fantasy and imagination, and imagination has a great moral benefits, and about this it is important to quote Margery Bianco's thought:

"Imagination is only another word for the interpretation of life. It is through imagination that a child makes its most significant contact with the world around him, that he learns tolerance, pit understanding, and the love for all created things" $"$.

Anyway, until the last decades of the eighteenth century the child does not exist as an important and continuous theme in English literature. The child as major theme comes with the generation of Blake and Wordsworth. With Blake's "The Chimney Sweeper" and Wordsworth's "Ode on an Intimations from Recollection of Early Childhood", appear as something essentially new, the poets expressed something they consider of great significance through the image of the child. For example Blake's innocence and Wordsworth's natural piety ${ }^{8}$. So during the course of few decades the child emerges from comparative unimportance to become the focus of an unprecedented literary interest, and, in time the central figure of an increasingly significant proportion of English literature. The appearance of the child is indeed connected with the end of the eighteenth century.

The child could serve as a symbol of the artist's dissatisfaction with society. In a world given increasingly to utilitarian values and machines, the child became the symbol of imagination and sensibility, a symbol of nature set against the forces abroad in society actively denaturing humanity'. Through the child the artist could express his awareness of the conflict between human Innocence the cumulative pressure of Social Experiences ${ }^{10}$.

Although since the end of eighteen century a small number of books had been produced specifically for children, the vast majority of such works were less concerned with catering to the needs and taste of their young audience than with providing instruction and offering examples to follow. In general the didactic fashion in books for children had drown from rather traditions: the fable, which offered examples of virtue and vice in action; and the emblem, which presented an object for contemplation, the allegorical or analogical significance being carefully disentangled and explained.

\section{3. "A rapid expansion of children' book market"}

Publishers of children' books in the first half of the century tended to be less interested in the profit than in inculcating specific religious, social and ideological precepts ${ }^{11}$; they subscribed to the prevailing idea that the child was born sinful and needed to be catechized into repentance and piety and all the pieces they published were intensely didactic. The idea of child as consumer grew gradually throughout the nineteenth century. Its evolution can be seen clearly in the records of the two largest evangelical publishing houses, The Religious Tract of Society (RTS) and Society for Promoting Christian Knowledge (SPCK) ${ }^{12}$. Their records suggest that much of the initial resistance to recognizing children as potential purchasers of books was bound up with the widespread reluctance to promote universal literacy which prevailed for much of the century ${ }^{13}$.

New readers of every age were attracted to the cheap and bawdy chapbooks, thrillers and comics which became increasingly plentiful as the century progressed. The evangelical publishing houses soon recognized the need to counter the attraction of cheap with lively and appealing works for their own.

In 1831 the SPCK formed its Committee of General Literature and Education to control the content of the books, but during 1880s commercial success had led even the most committed Christian publisher to reduce religious content,

\footnotetext{
${ }^{3}$ Geoffrey Summerfield op. cit. p. 83 .

${ }^{4}$ It is a collection of German fairy tales first published. The collection is commonly known in English as Grimm's Fairy

Tales. The first volume contains 86 stories, the last contains 211 tales.

${ }^{5}$ It is a satirical work of fantasy fiction, originally published in Christmas.

${ }^{6}$ Alice discovers a mad world that nevertheless manages to make a strange kind of sense. It is a form of writing that became a phenomenon in the mid- $19^{\text {th }}$ century.

${ }^{7}$ Bianco Margery, in Reynolds Kimberly, Girl only? Harvester Wheatsheaf London 1990 p. 39

${ }^{8}$ Cadma R., Irvine M., Responses, Edizioni scolastiche Bruno Mondadori, Milano 1989, p. 312

${ }^{9}$ Coveney The image of the childhood, quoted in Irvine M. Cadman R., cit. 312, nd

${ }^{10}$ Coveney in Irvine M. Cadman op. cit. 313, nd

${ }^{11}$ Reynolds Kimberly, Girl only? Harvester Wheatsheaf London 1990 p. 2

${ }^{12}$ The oldest Anglican mission organisation. It was founded in 1698 by an Anglican priest and a small group of friends.

The Society was founded to encourage Christian education and the production and distribution of Christian literature.

SPCK has always sought to find ways to communicate the basic principles of the Christian faith to a wider audience,

both in Britain and overseas.

${ }^{13}$ Reynolds Kimberly, op. cit p. 3
} 
increase the number of the entertaining features, and establish the practice of producing publications directed specifically at boys or girls rather than at young readers in generally.

After 1880 there is a rapid expansion of the children's book market, which includes adventures stories, historical fiction, school stories and in this period it is possible to see the emerging demarcation between books aimed at young readers of different sexes.

\subsection{Social and sexual stratification of education}

In this period also we see the acceptance of the existence of a literate working-class, and "education began to be considered an effective means of social control and a way of maintaining the status quo at a time when many social factors had undergone radical change" 14 . So there are significant changes in the aims of education with the Act of Education of 1880, but education given to the working-class was different from that received by the upper-class.

Working-class pupils were given a curriculum which attempted to insist on habit of obedience and frugality, but insufficient knowledge of political economy, so they were unable to interfere in master's decision; the middle-class, too were provided with an utilitarian style of education, adapted for their kind of work, and finally, by contrast the upperclass received a largely classical education. So education reforms were designed to strength on the existing social structure rather than enriching the intellectual lives of the working-force. There was also a different curriculum for girls and boys; and separate syllabuses were used for different sexes and different social classes, it helped, too, to maintain existing social division.

Girls studied subjects such as home economic, sewing and cookery, while boys were offered new options such as animal physiology, algebra, chemistry and physics, so girls areas of study were considered inferior to those of boys. All that means, there was a stratification of books in the field of juvenile publications. The purpose of this separation about books for different sexes, was to direct children towards their social and sexual identification. In fact in juvenile literature was presented the model of masculinity and femininity. The hero is characterized by rationality ${ }^{15}$, he is the holder, the creator, the discover or the defender, by contrast his ideal of woman ruled over the home, always agreeable and lovable. Examples of this model are in "Mr Midshipman Easy" (1836) and Ballantyne's "Coral Island" (1858), even if the heroes of such works often combined qualities associated with femininity.

\section{Male and female literature}

Two of the major writers of boys books were Henty and Reed. Henty began his writing career as a war correspondent when posted in Crimea, he wrote approximately 90 boys adventure stories and he introduced in his works, his own experiences, he left Cambridge and joned the hospital Commissariat of the army. The hero was the subject of a gradual progress, from a feeble adolescent into a massive man, and his life was free from moral conflict. Also Reed's young heroes lived his own experiences but he presents his hero as holder of problem and through his experiences he became free. In their works women substantially are weak so they are not able to be ambitious and her adventure and experiences prepare her to accept the role of woman. Instead two of the major writers of girls' books were Evelyn Everett-Green and L. T. Meade. The last one exercised too, her influence through the girls' literary magazine "Atlanta", this magazine tried to show that girls and young women had intellectual interest and sophisticated taste in literature. She believes that girls should be educated at home, and that their most important lesson was in self-control and her place was in the home and in moral environment based in feminine idealism. Evelyn Everett-Green attempt to instruct her readers about historical events creating fictional characters who lived in particular historical period ${ }^{16}$, in which there were political or social problems, such as religious intolerance, the Civil War or the Restoration period. But the image of woman in her books was essentially conservative, probably because she was not in favour of the behavior of the girls of the period and she tried to realised the woman traditional figure.

\section{Children' magazines}

The 1880 and 1881 see the beginning of two periodical, Boy's Own Paper and the Girl's own Paper ${ }^{17}$. The official plan was to attract readers with early numbers containing a high fiction entertainment content, and then, to increase the straightforwardly didactic Christian content, and to obtain this purpose the periodical were priced only a penny. BOP is formed of 16 pages and GOP is formed of 14 pages. A typical volume of BOP's fiction enphasise activity, independence and the triumph of the muscle and mind over adverse conditions, so man is presented as holder of rationality and strength. While woman is associated always with domestic ideal, she is a comfort for man, every experiences help her to understand what is important in life, and often the most important things presented the marriage and motherhood.

So there was an attempt to reconcile women to patriarchy. In all this, it was possible to see political enterprise to maintain woman's status quo, in a period in which there was a rejection of traditional roles and many woman thought to be denied about marriage and motherhood, and began in their minds to develop the idea of self-sufficiency and the independence from man. So all children's literature influenced the readers and the purpose of educators was to create a stereotype of male and female roles in a period of great change.

\footnotetext{
${ }^{14}$ K. Clarke, Public and private children: infant education in the 1820s and 1830s, Language, Gender and Childhood, quoted in Reynolds K., op. cit 9

${ }^{15}$ Reynolds K. Op. cit p. 51

${ }^{16}$ Reynold K., Op. cit p. 121

${ }^{17}$ Reynold K., Op. cit p. 139
} 


\section{References}

Ashley L., R. N. (1999) George Alfred Henty and the Victoria Mind, London, International Scholars. Book.

Bettlheim B. (1976) The uses of Enchantment: The meaning and Importance of fairy Tales. Book.

Cibaldi, A. (1976) Storia della letteratura per l'infanzia e l'adolescenza, La Scuola, Brescia,. Book

Erikson E., H. (1950), Childhood and Society, New York: Norton, p. 397.

Faeti, A. (1977) Letteratura per l'infanzia, La Nuova Italia, Firenze, Book.

Fenwick S. I. (1970) Genitori, ragazzi e libri, Armando, Roma. Book

Kimberly Reynolds, R. (1990) Girls Only-Gender and Popular Children's Fiction in Britain, 1880/1910 Harvester Wheatsheaf London. Book

Daphne Kutzer, M. (1977) “Empire's Children: Empire and Imperialism” in Classic British Children's Books, New York, Garland, 2000.

Newbolt, P. G. A. Henty: the earlier books for boys, 1871-1885, Antiquarian Book Monthly review, 4, 438-47. Essay in book.

Summerfield, G. (1984) Fantasy and reason. Children's Literature in the Eighteenth Century, Methuen \& Co. Ltd London. Book

Becker, G.S. (1993). Human Capital. Columbia University Press, New York. Book 